According to a recent decision by an IUGS Commission of Stratigraphy Working Group, the Jurassic-Cretaceous boundary is now to be fixed provisionally at the Tithonian-Berriasian boundary for the Tethyan province and at the Volgian-Ryazanian boundary for the Boreal realm. Although these levels are not synchronous they do correspond to most frequent usage and it is hoped that this recommendation will make things easier for non-specialists. This decision is a result of a unanimous vote by all members of the Working Group on the Jurassic-Cretaceous who were present at the 2 nd Cretaceous Symposium held in Munich last June.

A U.S. Department of Energy (DOE) geothermal demonstration project in the Baca field of the Valles Caldera, New Mexico, has recently been terminated because of difficulties in drilling and extracting hot fluids from this highly fractured structure. There are still active steam and gas vents 100000 years after the last major volcanic activity, and initial studies in the 1960 s and 1970 s led to estimates that eight 50 megawatt power plants could operate here for 30 years. However a drilling project begun in 1977 has resulted in only two successful wells out of 13 .

The main problem is the very complex fracturing which has shaped the valles Caldera. Hot water moving upward was under less pressure than the dril ling fluids, and there was a danger of drilling muds blocking permeable rocks intersected. Other problems included corrosion, breaking and loss of drill pipes, collapse of holes and casing, and of course the great difficulty of deciphering what rocks were being penetrated. How does one determine where in a jumble of fractures, faults and permeable zones there is freeflowing hot water? An attempt was made at hydrofracturing but the new fractures formed did not apparently intersect water-bearing zones.

Another problem is the low transmissivity of the Baca field relative to successful fields elsewhere. The process of extracting fluids would cool the rocks around the wells, reducing ambient water pressure and decreasing output.

With similar problems occurring elsewhere and with declining budgets DOE has now pulled out of nearly all its geothermal development projects to concentrate on the technical problems, including how to understand highly fractured volcanic systems.

A $\$ 4$ million project for upgrading the scientific and technological capabilities of the Jamaica Bauxite Institute (JBI) is now being carried out by UNIDO, the Vienna-based UN Industrial Developrnent Organization. Since mid-1981 new facilities have been designed, a laboratory constructed and an electron microscope and other equipment installed. JBI scientists and engineers have attended conferences, short courses and study tours in Hungary, France, F.R.G. and the U.S.A. The immediate aim of the project is to improve the processing of Jamaican bauxite to give Jamaica an economic edge in the ever more competitive aluminium industry. In addition to building up a capacity for sophisticated mineralogical work, the JBI will serve as a training centre and will be able to make its expertise available to other developing countries. When the first phase of the project is completed in 1983-1984, Jamaica will be the first developing country to have its own $R$ \& $D$ activities in bauxite mineralogy and processing comparable to those of industrialized countries.

A recent study of over 800 manganiferous chert deposits in the Franciscan formation of NW California confirms an old hypothesis that these represent the fossil remains of submarine hydrothermal events. Writing in the May issue of Economic Geology, D. Crerrar and associates from Princeton University point out that the deposits resemble the hydrothermal mounds discovered recently in the Galapagos Rift, the Gulf of Aden and the MidAtlantir Ridge. Fluid inclusions from veins in the deposits gave salinity values similar to those of seawater, temperatures near $200^{\circ} \mathrm{C}$ and hydrostatic pressure data corresponding to a water depth of $1700 \mathrm{~m}$. They note that the yearly flux of hydrothermal fluids at oceanic spreading centers of about $10^{17} \mathrm{~g}$ implies that the entire volume of ocean water could circulate completely every ten million years, controlling the composition of sea water and strongly influencing the geochemistry of the marine environment.
Recent studies of bubbles in ice of Pleistocene age suggest that the $\mathrm{pCO}_{2}$ content of the atmosphere was considerably jower during peak glacial times than during the Holocene. As W.S. Broecker of Columbia University (U.S.A.) points out in Geochimica et Cosmochimica Acta (1982, v. 46, 1698-1705), this change from low $\mathrm{PCO}_{2}$ in glacial times to high in postglacial must have been driven by changes in ocean chemistry, since the oceans contain about 50 times more $\mathrm{C}$ than the atmosphere. He shows that at the close of glacial time some 3\% of the $C$ in the atmosphere-ocean system was removed as organic residues, leading to a $\mathrm{CaCO}_{3}$ "preservation event" in the deep sea.

By considering the ${ }^{13} \mathrm{C}$ record Broecker connects this event with a decrease in the deep ocean $\mathrm{P} / \mathrm{C}$ ratio either through phosphorus removal to shelf sediments or involving a decrease in the $\mathrm{P}$ content in organic debris raining to the deep sea. If shelf storage is responsible for the $\mathrm{CO}_{2}$ increase then it is unlikely that this variation is a primary cause of climatic change since sea level changes would be required to drive deposition on and erosion from the shelves. On the other hand if changes in $\mathrm{C} / \mathrm{P}$ ratio of falling debris are responsible, then the $\mathrm{CO}_{2}$ change could be a primary cause of the glacial-interglacial cycle with "shelf sustained oscillations in ocean chemistry driven by interactions between ocean ecology and ocean nutrient chemistry".

Lake Chad which covers some 20000 $\mathrm{km}^{2}$ in central Africa, has long been a focus for study in view of the implications its oscillations in level have for the Quaternary climatic record. New evidence indicating three maximum levels at around 30000, 22000 and 12000-8000 years $B P$ has been described recently by $A$. Durand of the Service de Geologie de Niger in Palaeogeography, Palaeoclimatology and Palaeoecology (1982, v. 39, p. 37-53). The levels reached by these large ancient lakes were never much higher than the present level of $279-282 \mathrm{~m}$, and there is no sign of any major variation over the last 8000 years. The hypothesis of a huge $\left(320000 \mathrm{~km}^{2}\right)$ palaeolake Chad reaching a $320 \mathrm{~m}$ level around 6000 years ago is now discarded by Durand. 


\section{* * * * *}

The idea that many orogenic belts contain large tectonic slices which originated elsewhere and were moved into place by ocean floor spreading along major fault zones is gaining ground for the Appalachian orogen. $H$. Williams of Memorial University of Newfoundland and R.D. Hatcher Jr. of the University of South Carolina argued recently that the Appalachians contain a variety of "structurally uncoupled and therefore suspect" terranes (Geology, 1982, Vol. 12, p. 530536). These large-scale fault-bounded units appear to have been added to the North American miogeocline in a progressively eastward direction. Accretionary events correspond to periods of major deformation, plutonism and metamorphism from early Ordovician to Carboniferous time. Williams and Hatcher point out that the suspect-terrane concept emphasizes palaeogeographic uncertainties but provides a fresh approach to orogenic syntheses, since episodic orogenic events can be easily accomodated to continuous orogenic processes based on the complexities of modern oceans.

Meanwhile on the west coast of North America, U.S. geologists P.J. Coney, D.L. Jones and Norman Silberling have recognized as many as 100 suspect terranes ranging in area from a few tens of square metres to over 175000 $\mathrm{km}^{2}$. Most of these land masses are believed to have been derived in the period from about $200 \mathrm{Ma}$ to $50 \mathrm{Ma}$ ago from unknown sources in the Pacific and carried by the spreading oceanic plate to be added through a process of "accretionary tectonics" to the western edge of North America, increasing its size by some $30 \%$. Recent palaeomagnetic studies also show that parts of what is now southern Alaska were in an equatorial position around 200-240 Ma ago. Some of these parts appear to have been accreted 50-60 Ma ago, while others may be "docking" only now, such as the arcs around Yakutat in the Gulf of Alaska.

The U.S. National Petroleum Council has set up a Committee on Third World Petroleum Development to encourage development of indigenous energy resources in developing countries that import oil. The Committee was asked to focus on factors that affect the decisions of business to explore for and develop oil and gas in Third World nations.

\section{* * * * *}

The eruption of the Mexican volcano El Chichón in March and April of this year has generated widespread interest because of its likely effect on global climate. Located in a volcanically active gap between the Mexican and Central American volcanic belts, El Chichón's series of Plinian and volcanian eruptions caused great havoc locally through basal surges, pyroclastic flows and tephra deposits. Ash samples showed high sulphur contents, which were also reflected in the gas phase. The fine ejecta formed a cloud which two days af ter the eruption covered an area of $2.8 \times 10^{6} \mathrm{~km}^{2}$. This has since spread to latitude $30^{\circ} \mathrm{N}$ and satellite observations have shown traces of the volcanic cloud as far apart as $60^{\circ} \mathrm{S}$ and $40^{\circ} \mathrm{N}$. Satellite measurements taken recently indicate that the cloud contained $3.3 \times 10^{6}$ tonnes $\mathrm{SO}_{2}$

With the eruptive plume rising to over $30 \mathrm{~km}$ height, a great deal of research is now underway to determine the possible climatic effect of the high $S$ content and the sulphuric acid aerosols formed. El Chichón also releases considerable amounts of $\mathrm{NaCl}$ into the upper atmosphere, and some workers anticipate a possible destruction of ozone in the stratosphere as a result of chlorine-triggered reactions. Several calculations indicate that the cloud may lead to a global cooling in the next few years of $0.5^{\circ}$ to $1^{\circ} \mathrm{C}$, though this will be difficult to detect because of the natural variations in temperature worldwide.

In November 1981 a magnitude 5.5 earthquake occurred under a large embayment in Aswan Lake $60 \mathrm{~km}$ southwest of the Aswan Dam. Aftershocks clustered near the surface trace of the E-W Kalabsha Fault at focal depths of about $20 \mathrm{~km}$, according to recent reports by D.W. Simpson, C. Nicholson, T.R. Toppocada (all of the USA) and their colleagues in the Egyptian Geological Survey and the Helwan Institute of Astronomy and Geophysics. An average of 5 - 10 seismic events per day were recorded between July and September 1982. The absence of previous earthquakes of M5 or greater in this region suggests that the seismicity was triggered by the filling of Aswan Lake. In 1976, twelve years after the dam was closed, the lake reached its maximum depth of $92 \mathrm{~m}$, with the total water volume of 150 $\mathrm{km}^{3}$ making it the second largest reservoir in the world. Seismic activity detected in other localities within 50 $\mathrm{km}$ of the dam may indicate activity along other nearby faults too.

The art of lineament analysis continues to thrive among geoscientists who delight in identifying and analyzing linear topographic, geological or biological elements recognized from a map, aerial photograph or satellite image. Donald U. Wise (U.S.A.), writing in the Geological Society of America Bulletin, v. 93 (886-888), 1982, proposes 32 rules which "if followed carefully should ensure the long-term preservation of ... Linear Geo-art ..., unblemished by any taint of science." These guidelines, which deserve csareful thought, include the following: The first task is to generate lines, "the more the better," for it is not their quality which counts but "their number and potential for compilation into artistically pleasing patterns.

In detecting lineaments the more sophisticated, modern and expensive the equipment used, the more significant the data must be.... Sophisticated population-density contouring of numbers of lineaments per $\mathrm{km}^{2}$ of certain areas has proven that fewer natural lineaments are observable in urban areas or over large lakes than in open country. Thus computer processing of lineament maps derived from satellite images can help identify ... previous unrecognized cities and lakes."

"Never define the ages of 'orthogonal' sets of lineaments too precisely. Differences of a few $100 \mathrm{Ma}$... are not very significant when compared to the beauty of such patterns.... Any acute angle between two lineaments may be bisected to derive the direction of maximum compressive stress. It is not necessary that both lineaments be of the same age; the fact that they intersect is adequate.... If one line terminates against another, always assume that an older line has been cut off along a younger fault line. Never hint that an older fracture can form a boundary discontinuity against which younger faults can terminate. ... Each successive fracture episode is the very first to break an area. This assumption of eternal crustal virginity assures mechanical isotropy of an area and does not confuse readers with such complicated concepts as tectonic heredity and pre-existing influences on fracture directions." 